\title{
Occupational Health and Safety Hazards in Machining
}

Danuse Madlova ${ }^{1}$, Vlastislav Gebhart ${ }^{2}$

${ }^{1}$ Faculty of Production Technology and Management, J. E. Purkyne University in Usti nad Labem. Pasteurova 3334/7, 40001 Usti nad Labem. Czech Republic. E-mail: madlova@fvtm.ujep.cz

${ }^{2}$ Gebhart. Skrivan 78, 27021 Pavlikov. Czech Republic. E-mail: gebhart.vl@seznam.cz

This paper is focused on occupational health and safety hazards in machining processes. Problem is specified on employs and employers. Occupational health and safety is based on legislative regulations. Safety rules are usually formulated generally. But it is necessary to formulate safety rules more precisely for different production processes and even for different production machines. And this has not been fully satisfactory solved, especially from the point of view of the development of machine tools, their automation and also from the viewpoint of the development of cutting materials. In the paper principal occupational health and safety hazard in machining will be formulated on the base of laws, regulations and personal findings of the paper's authors in different enterprises. As an example safety hazards and safety rules will be in depth formulated for turning. Similar health and safety rules and hazards must be formulated for other cutting processes. But occupational health and safety problems relate not only to persons but also to enterprise economy.

Keywords: Risk, Occupational health and safety, Legislation, Employer, Employee

\section{References}

[1] VASILKO, K., PILC, J. (2013). New Technological Knowledge of the Rotary Turning Tool. In: Manufacturing Technology, Vol. 13, No. 4, pp. $571-575$.

[2] KOCMAN, K., PROKOP. J. (2001). Techologie obrábění, 271 p., CERM, Brno.

[3] HOLESOVSKY, F., NAPRSTKOVA, N., NOVAK, M. (2013). GICS for Grinding Process Optimization. In: $M a-$ nufacturing Technology, Vol. 12, No. 12, pp. $22-26$.

[4] http://makezine.com/2011/04/14/yale-student-killed-in-lathe-accident/.

[5] http://www.hse.gov.uk/press/2010/coi-nw-34autoy.htm.

[6] http://press.hse.gov.uk/2015/internationl-tyre-firm-fined-after-17-year-old-apprentice-injured-in-lathe/

[7] 262/2006 Sb. Zakonik prace (CZ Labour code).

[8] Zakon 309/2006 Sb. (CZ law related to occupational safety and inspection), ,

[9] Zakon 251/20065 Sb. (CZ law related to labour inspection).

[10] Zakon 372/2011 Sb. (CZ law related to health services).

[11] Vyhlaska 432/2003 Sb. (CZ government ordinance).

[12] Narizeni vlady 378/2001 Sb. (CZ government order).

[13] Narizeni vlady 201/2010 Sb. (CZ government order).

[14] Narizeni vlady 495/2001 Sb. (CZ government order).

[15] European occupational health and safety regulation EHS 89/391.

[16] KOUBEK, J. (2007). Rizeni lidskych zdroju. 399 p., Management Press, Praha.

[17] http://www.suip.cz/_files/suip-b110a5cb403edcb12e206b5aebd1242/bezpecny_podnik_cj.pdf. 